\title{
Teachers' Self Efficacy: Is Reporting Non-Significant Results Essential?
}

\author{
Smitta Waitshega Tefo Moalosi, University of Botswana, Botswana
}

\begin{abstract}
Self-efficacious teachers are viewed as having the ability to organize relevant activities, patient with students who are struggling in learning, and spending more time designing relevant teaching activities. The teachers exhibit good performance and probably remain committed to their work. And they are committed to organizing appropriate teaching activities, engaging students in learning. Teachers with high self-efficacy keep students on task and perform better because they use innovative teaching methods that encourage students' autonomy and reduce custodial control. The main purpose of this paper is to report non-significant findings of a study that was carried out in Botswana with 1000 junior secondary school teachers in Gaborone and surrounding areas between November 2010 and February 2011. The study was about teacher efficacy and classroom management among Botswana junior secondary school teachers. Teacher Sense of Efficacy scale (TSES) instrument was used to collect data for the study. TSES comprises of three subscales, Efficacy in Student Engagement, Instructional Strategies and Classroom Management. Efficacy in Student Engagement was the only significant subscale among other sub-scales of TSES. The TSES means of districts, cities, towns and villages were not significant. This prompted the researcher to report non-significant results because they can assist teacher educators and stakeholders on how best to improve the training of pre-service and in-service teachers. Teacher commitment to work can enhance student learning. Teacher effectiveness can also promote positive effect in student learning, because teachers can plan their work using relevant materials that can motivate students to learn. Managing classrooms can enhance student learning if teachers encourage students to be responsible to their learning, and can put students on task and to reduce students' undesirable behaviors that may interfere with their learning.
\end{abstract}

Keywords: Teacher Self-Efficacy; Teacher Commitment; Classroom Management

\section{INTRODUCTION}

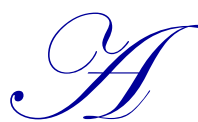

body of research agrees with Bandura's social cognitive theory, of which self-efficacy is a component. According to Bandura (1997) most research is supportive in regard to self-efficacy particularly on human behaviors in different environments, for example, education, health, sports, and business. Therefore, in academic settings, research has found that self-efficacy beliefs of students are vital and have an impact on 'achievement and behavior' In addition research has shown that teachers' sense of self-efficacy has a major role in affecting essential results for teachers as well as the students (Klassen, Tze, Betts \& Gordon, 2011).

Teachers' self-efficacy is viewed as influential in regard to student achievement and motivation. Also teachers 'self-efficacy has proven to be having a positive effect on the beliefs of teachers about teaching and instructional methods (Skaalvik and Skaalvik 2007; Tschannen-Moran and Woolfolk Hoy 2001). Betoret, (2006) reported that teachers who have a low teachers' self-efficacy encounter more problems in teaching and are not satisfied in their work and experience higher level of job- related stress.

The above mentioned definitions of teacher self-efficacy are vital because they imply that teachers with high self-efficacy can influence students in regard to different instructional strategies. However, there is a concern with non-significant results of Botswana junior secondary school teachers; will the students be influenced for 
positive learning? If teachers rated themselves using similar instructional methods, we do not know if teachers help students effectively in learning because more students in junior secondary schools have failed rather than passing (e.g. Dibapile, 2011).

High self-efficacy is important it enables teachers to be effective in their work. Self-efficacious teachers are viewed as having the ability to organize relevant activities, they are patient with students who are struggling in learning and they spend more time designing relevant teaching activities. Similarly, "the teachers will exhibit good performance and probably remain committed to their work" (Ware \& Kitsantas, 2007, p. 303). When teachers organize appropriate teaching activities, it shows that they engage students in learning and are commitment to their work. Podel and Soodak, (1993) reported that teachers with high self-efficacy keep students on task. Cousins and Walker, (as cited in Erawan 2010) found that teachers with high self-efficacious beliefs are likely to perform better than those with low self-efficacy beliefs because they "implement didactic innovations in the classroom and use classroom management approaches and adequate teaching methods that encourage students' autonomy and reduce custodial control" (p. 252).

Teacher commitment to work is essential in the teaching profession, and teachers who are committed do not make their students only proud but the employer and their society at large. Teachers who have a desire to impact student learning tend to show commitment to their work. Research in educational psychology shows "that a teacher's quality of performance and commitment to work is related to his/her level of motivation to influence student learning" Bandura (as cited in Ware and Kitsantas, 2007). This motivation is also import in teacher efficacy construct because it is where teachers will feel efficient to assist students in learning as well as the teachers' instructional attempts in choosing activities, 'level of effort' and patience with students (Tschannen-Moran and Woolfolk-Hoy, 2001). Other researchers have found that teacher efficacy has an impact on "performance, commitment, and professional retention" (Ware \& Kitsantas, 2007, p. 303).

Teacher effectiveness might be a solution, to different factors that contribute to lack of effective teaching as it can have an impact on high teacher efficacy. Thus, teachers can impact students for lifelong learning. This writer is not intending to discuss teacher effectiveness in detail, but rather to highlight its relevance to effective teaching. Hence performance of teachers could lead them to commit themselves to their vocation and have a positive effect on students 'education.

\section{TEACHER EFFICACY AND TEACHER EFFECTIVENESS}

According to Tournaki, Lyublinshaya, and Carolan (2009), teacher effectiveness is comprised of three factors listed below:

\section{Planning and Preparation}

Teachers who are effective can succeed in planning and preparing their work. They also possess knowledge of their teaching materials and a clearly defined pedagogy. They are able to choose their instructional objectives, to create consistent instruction, as well as to evaluate students as they teach (Tournaki et al., 2009). However, teachers who chose teaching because of job security may not take much responsibility in planning and preparation and therefore, problems in education will emerge.

\section{Classroom Environments}

Effective teachers are viewed as experts in classroom management. However, with large classes it may not be easy to see expertise of teachers when they handle many students. Classroom management includes "noninstructional personal interactions" (Tournaki et al., 2009, p. 98) that happens within the classroom environment. Therefore, relationships can be formed where a teacher respects students as well as managing the classroom effectively. 


\section{Instruction}

Effective teachers develop student learning through interactive instruction. Effective teachers increase students' accomplishments by facilitating active learning. Questions and discussions and other methods that aid learning are essential forms of instruction. When students are given feedback on their work and are being made aware of their progress in learning, teachers are viewed as using "effective teaching techniques and communicating with clarity and accuracy" (Tournaki et al., p. 98). When effective teachers plan and prepare their work, the classroom becomes what Greenberg (2005) calls "a laboratory for learning..., for the learning community places a great value on every class member's developing an understanding of the process of learning, and the classroom atmosphere enhances the possibilities of high quality... learning experiences" (p. 41).

Considering how effective teachers become experts in helping students to learn is useful in establishing responsibility in teaching, which reduces problems in education. Ross and Bruce (2007) contend "more effective teaching should increase the likelihood of teachers obtaining mastery experiences, the strongest predictor of selfefficacy" (p. 6).

Effective teachers act as mediators as they interact with learners. The instruction of effective teachers can be conceived as "scaffolded" instruction that support learners in benefiting from objectives. Learners may not achieve this benefit without the support of effective teachers (Ashman and Conway, 1997). In this scenario, learning can be thought of as "mediated by an expert guiding a novice through a task to ensure the learner acquires the expert's skills" (Ashman \& Conway, 1997, p. 137). Teacher self-efficacy is essential in education and can play a major role in overcoming problems teachers encounter in their work. For example, lack of planning and preparing their work which will lead to effective instruction. Coaching teachers in their profession is important because it will have a positive impact on their efficacious beliefs.

\section{BACKGROUND}

Research on teacher efficacy and classroom management is lacking in Botswana as well as in other African countries. Klaseen, Tze, Betts, and Gordon (2011) investigated studies of teacher self-efficacy from 1998 to 2009, using Psyc info, Web of science and Eric databases to search for articles written in English. They reported only 2\% of such studies were conducted in Africa, but did not mention the specific countries where the research occurred.

The research of Magogwe and Oliver (2007) was based on "the relationship between language and learning strategies, proficiency, and self-efficacy beliefs of students in Botswana" and found that the students used average self-efficacy beliefs in "their learning of the English language although not consistently so" (p. 350).

Brandon (2000) investigated gender differences' effect on self-efficacy of prospective teachers in Botswana's four primary teacher colleges. Her study focused on the beliefs of males and females students and their abilities to engage in teaching activities. The instrument used in Brandon's study was Likert-type and included 16 items that measured students' behaviors. Brandon found that female pre-service teachers had lower self-efficacy in "specific teaching competences" than males prior to going into the field. Both these studies analyzed students' selfefficacy, leaving teacher efficacy under researched.

Since studies on teacher efficacy hardly exist in Botswana, this researcher investigated Botswana junior secondary school teachers' sense-of efficacy and classroom management. The results of the study will benefit teacher educators, the ministry of education, and stakeholders and will point to ways to improve Botswana's teacher education in general.

\section{PURPOSE OF THE STUDY}

The study's purpose was to examine three aspects of teacher efficacy: student engagement, instructional strategies and classroom management among Botswana junior secondary school (JSS). However, the paper will focus on the importance of reporting non-significant results as they can enable teacher educators, ministry of education and stakeholders to improve the training of teachers as well as on in-service teachers. 


\section{RESEARCH QUESTION}

The study is guided by the research question: For Community Junior Secondary School teachers in Botswana, what relationships, if any, exist among the three sub-scales of the TSES: Student Engagement, Instructional Strategies and Classroom Management? Previous research in the United States of America showed significant relationships among the three subscales. This study is being conducted to determine whether this relationship also exists in Botswana.

\section{RESEARCH DESIGN}

The study used quantitative survey research which investigated teachers' efficacy beliefs among junior secondary school teachers in Botswana. Data was derived using the survey method by requesting teachers to complete a questionnaire. The Teachers' Sense of Efficacy Scale only measures teachers' self-efficacy. TschannenMoran and Woolfolk's (2001) Short Form instrument was used to assess the Botswana junior secondary school teachers' responses. The Short term scale comprises of 12 items in which four items each measure, Efficacy in Student Engagement, Instructional Strategies and Classroom Management respectively.

\section{POPULATION AND DATA COLLECTION}

Data were collected from junior secondary school teachers in Gaborone, the capital city of Botswana and surrounding areas. Surveys were distributed to 7 of the 15 junior secondary schools in Gaborone. Survey questionnaire were also distributed in surrounding villages. Teachers in used schools volunteered to complete the questionnaires and there were no incentives given to them for participating.1006 teachers participated in the study and 6 did not complete the survey.

The sample of teachers who participated in the study were selected by the researcher and assistants, when visiting the schools, meeting with teachers in the staffrooms and explaining the purpose of the research as well as giving them letters asking them to participate in the study. Teachers' participation was voluntary. The research team selected half of the schools in each area. For example, the capital city (Gaborone) has 15 schools and only seven schools participated. In small villages with one school, the questionnaires were distributed to all teachers, but not all teachers completed them since participation was voluntary. Data were collected mid November 2010 until the end of February 2011.

\section{DATA ANALYSIS}

The data were coded and analyzed using the Statistical Package of Social Sciences (SPSS), a computer program. Birley and Moreland (1998) defined coding as "the process of assigning a symbol as a shorthand way of summarizing a completed questionnaire response. Typically numbers and or letters are used in coding" (p. 58). Salkind (2006) added that "data are coded when they are transferred from the original collection form (such as a test booklet) into a format that leads itself into data analysis" (p. 148). Data collected from the participants was transferred from the survey forms into SPSS spread sheets. Possible mistakes in the data were checked by the researcher and assistants; it was a process of viewing every variable questionnaire to make sure that there was no missing information. The gender variable was coded 1 .

Table 1: Showing Instructional Strategies Results ANOVA

\begin{tabular}{|l|c|c|c|c|c|}
\hline \multicolumn{1}{|c|}{ TSES_IS } & Sum of Squares & df & Mean Square & F & Sig. \\
\hline Between Groups & 129.677 & 6 & 21.613 & 1.060 & .385 \\
\hline Within Groups & 20363.636 & 999 & 20.384 & & \\
\hline Total & 20493.312 & 1005 & & & \\
\hline
\end{tabular}

The TSES subscales' means are not significant for Efficacy in Instructional Strategies and qualifications. The results show junior secondary school teachers in Botswana did not differ in their ratings on how they use instruction in their classrooms. These findings could be expected to be different because Botswana teachers are 
trained in different teacher training institutions, so their teaching methods are different. For example, most teachers are Diploma holders trained in one of the two colleges offering a three-year course in secondary education. The majority of degree holders are graduates of the University of Botswana. Teachers with a Post-Graduate Diploma in Education (PGDE) spent four years studying for a Bachelor of Arts degree and one year taking a teachercertification course.

Graduates from both institutions could be effective in their work, differing in their instructional methods because they received their training from different institutions and because the curriculum they were exposed to was different. Therefore, how they engage students and manage classrooms may be different.

Regarding the current study's findings, teachers' not reporting differences in instructional strategies is not new with teachers in Botswana. Fuller and Synder (1991), who studied teacher-centered approaches in primary and junior secondary Botswana schools, stated that surprisingly most of the time "... the vast majority of teacher questions are closed-ended, demanding simple recall" (p. 292). This writer thinks that if the teacher is the director in student learning, students may not be involved much in their work, they can depend on the teacher. Hence they can fail because they are not actively involved in learning.

Classroom management is another element that that is important in education. Students cannot be focused when there are disturbed in learning. It is important for every student to feel the freedom of learning without unnecessary disturbances in the learning environments.

\section{CLASSROOM MANAGEMENT}

Classrooms that are well managed by teachers are conducive for students' learning. Stenberg and Williams (2002) define classroom management as "a set of techniques and skills that allow a teacher to control students effectively in order to create positive learning environment for all students" (p. 384). This implies that a teacher who is skilled can impact students to do well in learning. He/she has to involve all students in learning. Referring to the table below, the results shows that regardless of the places where teachers are, or originate from, they still could not manage the students 'learning well. Therefore, it is worth reporting these results because they reveal what is happening in Botswana classrooms. This writer thinks that it is useful for teacher educators to raise awareness of teachers about the goals of classroom management as suggested by Sternberg and Williams (2002). The goals of classroom management are discussed.

- $\quad$ Creating an environment that increases student learning; where teachers will use good management strategies that will improve learning. Accordingly, management strategies that make students to be quite in the classrooms does not improve student learning with few students involved in conversations. Some teachers train students to be quite in class while their behavior does not show that they gain form learning. Therefore, teachers should ask themselves questions about their management strategies if they are influencing the learning setting positively (Stenberg \& Williams 2002).

- $\quad$ Allocated versus engaged time: Evaluating classroom strategies is one of the important ways teachers can use to assess the time students have in learning. Allocated is viewed as the time teachers keep as well as plan to use it for students 'learning. Thus engaged time is the time students' use as they learn.

- $\quad$ Promoting self- management: The main goals of classroom management are to assist students to be mature in the process of learning as well as managing themselves. Also to help students use rules and techniques that have an effect in learning Sternberg and Williams (2002). For example, self- management one of the behavioral techniques, "Is the control people maintain over their learning" (p. 388). Thus, to help students to develop their capabilities as well as understanding, controlling and assessing their learning, will enable teachers to assist students for maturity for lifelong learning Kremer and Tillema (as cited in Sternberg \& Williams, 2002). Accordingly, to be successful with the aims of helping students to be mature is to raise their awareness on the importance of being responsible for their learning. 
Table 2: The Results of Classroom Management by Cities, Towns, Villages and Districts ANOVA

\begin{tabular}{|l|c|c|c|c|c|}
\hline \multicolumn{1}{|c|}{ TSES_CM } & Sum of Squares & df & Mean Square & F & Sig. \\
\hline Between Groups & 29.934 & 4 & 7.483 & .480 & .750 \\
\hline Within Groups & 15551.159 & 998 & 15.582 & & \\
\hline Total & 15581.093 & 1002 & & & \\
\hline
\end{tabular}

The results of Classroom management by cities, towns, villages and districts are not significant (Table 2). The above results causes concern because it shows that teachers from different places in Botswana rated themselves the same, and have a low teacher efficacy in how they manage the classrooms. How can then students be expected to perform better while teachers lack management strategies that could enhance learning? Social cognitive theory proposed by Bandura, (1977) advocates for self-efficacious beliefs in regard to teacher behaviors that are important in educational settings. Also, teachers with a high efficacy are perceived as being able to perform better and use activities in their work that have a positive impact on students' learning. Thus, teachers with high self-efficacy beliefs are needed in education because they will also have classroom management skills that encourage students to be creative and manage their learning well for better performance. Table 2 shows that classroom management seems to be a challenge to teachers. Also instructional strategies by gender showed that males and female teachers rated themselves similar in regard to different methods of teaching they use in classrooms. The ministry of education has to pay more attain to teachers in general so that low performance of students can be reduced.

Table 3: Showing Instructional Strategies and Gender ANOVA

\begin{tabular}{|l|c|c|c|c|c|}
\hline \multicolumn{1}{|c|}{ TSES_CM } & Sum of Squares & df & Mean Square & F & Sig. \\
\hline Between Groups & 55.632 & 1 & 55.632 & 2.733 & .099 \\
\hline Within Groups & 20437.680 & 1004 & 20.356 & & \\
\hline Total & 20493.312 & 1005 & & & \\
\hline
\end{tabular}

The table above shows that males and females did not differ in how they manage the classroom behaviors; also teachers with longer teaching experience did not differ with those least experience. However, reflecting on the current study's results, this writer thinks they are examples of teachers' views on career choices and related beliefs that can be understood in terms of the career stages Huberman proposed (as cited in Klassen \& Chiu, 2010). Huberman asserted that teachers that have taught four to six years' experience "stabilization," characterized by either devotion to their occupation or the decision to resign. For example, according to Huberman, teachers with three years of teaching experience have "stabilized" if they use the same instructional and disruptive behavior management methods as teachers with 21 years of teaching experience. However, Huberman said more experienced teachers, having taught 19 to 30 years, are prone to "serenity," the "gradual loss in energy and enthusiasm [that] is compensated for by greater sense of confidence and self-acceptance” (Klassen and Chiu, 2010, p. 748).

This writer agrees with Huberman that experienced teachers' ability to work and motivate is declining when their performance is the same as the least experienced. Experienced teachers should perform better than those with less experience. Other researchers - for example, Imants and DeBrabander, Lin et al., and Mertler (as cited in Cheung, 2008) - suggested teaching experience as having an impact on teacher efficacy. Their findings indicated that teaching experience is associated with teachers' "perceived efficacy" as well as "school efficacy." Perceived efficacy, as suggested by Bandura (1993), has an impact on academic growth.

Therefore, the implication is that the more teachers lack perceive efficacy, the less their students grow academically. Also, more experienced teachers are viewed as having the ability to cope in various circumstances "and handle different situations and thus critically reflect on these situations, which can help them grow and handle similar situations better or in more mature ways the next time they occur" (Cheung, 2008, p. 116). Wolters and Daugherty (2007) found that more experienced teachers were confident of their capabilities to "employ instructional and assessment practices that would benefit even the most difficult-to-reach students" (p. 188). The present study's results, however, contrast with the studies mentioned above. In the present study, the majority of teachers have been teaching from six to twelve years, representing the middle of their career. 
According to Huberman, teachers in mid-career is in the stage of "experimentation and activism" and is evaluating their jobs and career decisions. The "experimentation and activism" stage is critical because it involves experimenting with the vocation and either putting forth effort or not, probably even with a "take it or leave it" attitude, which means those teachers can either continue working or quit. Therefore, if teachers believe they have made the right choices in becoming teachers, they can have a high sense of efficacy in terms of the three efficacy subscales (Student Engagement, Instructional Strategies and Classroom Management). However, if they think they made the wrong choice in becoming teachers or have chosen the teaching profession for different reasons than those mentioned above in TSES's three subscales, these teachers may not have a positive effect on student learning (O’Mara, 1996; Dibapile, 2005). Day and Gu (as cited in Klassen \& Chiu, 2010) reported that the majority of teachers in the middle of their vocation "(i.e., 8 -23) experience increases in motivation and commitment, whereas increased proportions of teachers in the later stages of their career (24+ years of experience) report declining motivation" (p .748).

In the present study, teachers with more than 20 years' experience performed slightly higher in terms of classroom management than those with less experience. These findings are consistent with Day and GU's findings that experienced teachers were motivated and took responsibility in their career. Gorrell and Dharmadasa (as cited in Fives \& Buehl, 2010) reported that teachers with more experience have a high efficacy regarding classroom management Tschannen-Moran and Woolfolk Hoy (2007) reported the same findings.

\section{CONCLUSION}

Reporting non-significant results is useful because they can enable teacher educators and stakeholders to improve more the training of teachers as well as assisting in - service teachers to be more committed their work. Collaboration where teachers work together in groups and cognitive coaching where teachers share ideas about their work and learn from each other are vital. Learning from each other will enable teachers to practice what they have learnt from each other in their classes hence students will benefit from that collaboration. From the sample schools in Botswana teachers work together in groups. They can take advantage of and engage students more in learning. Reflecting to what is discussed earlier, about results that are not significant in districts, towns and villages; it also shows that some teachers have a low teacher efficacy. Thus, it is important that teachers should have a high teacher efficacy. Because it will enable them to be patience and work with low achieving students and be motivated to help them in the learning environments. The no-significant results reveal that teacher in districts; villages and towns rated themselves low in the subscales of Teachers' Sense of Efficacy Scale.

Therefore professional development and coaching teachers are necessary as they will be encouraged to engage students more in learning. Career stages suggested by Huberman discusses earlier in this paper sheds light on our understanding of teaching experience of teachers. It reveals the stages of their careers and how well they can contribute to their profession with such experiences. Attention can be paid to every career stages for example beginning teachers are still exploring the work place and may not be effective in their work because they may have other career options. They may be in the experimentation and activism stage, and if their expectations of the teaching profession are not met due to work related challenges they may choose to leave the profession. Also more experienced teachers may lose motivation because of long service and professional burnout. Thus, a need to assist teachers to be committed in their work is important. Student engagement is also important in education, because students cannot perform better when they are not involved and assisted to take responsibility in their learning. Teacher effectiveness may enable teachers to plan instruction that can challenge students' cognitive abilities during learning.

\section{AUTHOR INFORMATION}

Smitta Waitshega Tefo Moalosi is a lecturer at the Department of Educational Foundations, University of Botswana in Southern Africa. She teaches courses in Educational Psychology. She holds the following qualifications: Diploma in Counseling Studies, Keele University (England, UK) Bsc. Psychology, Bolton Institute of Higher Learning, (England, UK) and M Ed. Psychology of Education, Bristol University, (England, and UK). Smitta is currently a doctoral candidate at the University of Tennessee, Knoxville USA. Her research interests are: teacher efficacy, classroom management, reasons for choosing teaching as a career, self-concept and adolescent development. E-mail: smittawd@yahoo.com and sdibapil@utk.edu 


\section{REFERENCES}

1. Adedoyin, O.O. (2007). Factor-Analytic of teacher's perceptions on self- efficacy in Botswana junior secondary schools: Implications for educational quality. European Journal of Educational Studies, 2, 2 , 139-155.

2. Ashman, F., \& Conway, R. (1997). An introduction to cognitive education. London: Routledge.

3. Ashton, P. T., \& Webb, R. B. (1986). Making a difference: teachers' sense of efficacy and student achievement. New York: Longman.

4. Bandura, A. (1997). Self-efficacy: The exercise of control. New York: Freeman \& Company.

5. Bandura, A. (1993). Perceived self- efficacy in cognitive development and functioning. Educational Psychologist, 28, 2, 117-148.

6. Bandura, A. (1977). Self-efficacy: Towards a unifying theory of behavioral change. Psychology Review, 84(2), 479-507.

7. Brandon, D. B. (2000). Self-efficacy: gender differences of prospective teachers in Botswana. Research in Education, 64, 36-42.

8. Betoret, F.D. (2006). Stressors, self-efficacy, coping resources, and burnout among secondary school teachers in Spain. Educational Psychology, 26, 519-539.

9. Cheung, H. Y. (2008). Teacher Efficacy: A comparative study of Hong Kong and Shanghai primary inservice teachers. The Australian Educational Researcher, 35, 1, 103-123.

10. Cousins, J., \& Walker, C. (1995). Predictors of educators' valuing of systemic inquiry in schools. Journal of Program Evaluation, Special Issue, 25-35.

11. Darling-Hammond, L. (2003). Keeping good teachers: Why it matters what leaders can do? Educational Leadership, 60, 6-13.

12. Dibapile, W. T. S. (2005). An analysis of the reasons offered by post-graduate diploma in education students in Botswana for opting teaching as a career. Journal of College Teaching, 2, 1, 75-85.

13. Dibapile, W.T.S. (2012). A Report of the responses of botswana junior secondary school teachers on the three subscales of teachers sense of efficacy scale (tses). Journal of International Education Research, 8, 2, 145-154.

14. Erawan, P. (2010). A comparison of teaching efficacy commitment to teaching: Profession satisfaction with program effectiveness of teacher students under 5 year program curriculum and those under $4+1$ year program curriculum. European Journal of Social Sciences 14, 2, 250-261.

15. Fives, H., \& Buehl, M. M. (2010). Examining the factor structure of the teachers' sense of efficacy scale. Journal of Experimental Education, 78, 118-134.

16. Fuller, B., \& Synder, J. C. W. (1991). Vocal teachers, silent pupils? Life in Botswana classrooms. Comparative Education Review, 35, 5, 274-294.

17. Gibson, S., \& Dembo, M. H. (1884). Teacher efficacy: A construct validation. Journal of Educational Psychology, 76, 569-582.

18. Guskey, T. (1988).Teacher efficacy, self-concept, and attitudes toward the implementation of instructional innovation. Teaching \& teacher education 4, 63-69.

19. Greenberg, K. H. (2005). The cognitive enrichment advantage: Teacher Handbook. Knoxville: KCD Harris and Associates.

20. Klassen, R. M., Tze, V. M. C., Bets, S. M., \& Gordon, K. A. (2011). Teacher efficacy research 1998-2009: signs of progress on unfulfilled promise? Elementary School Journal, 93, 356-372.

21. O'mara, F. R. (Ed.). (1996). Students reasons for becoming teachers: The case of first year students at Molepolole College of Education. Gaborone: Heinemann Education Publishers.

22. Podell, D., \& Soodak, L., (1993). Teacher efficacy and bias in special education referrals. Journal of Education Research. 86, 247-253.

23. Ross, J. A., \& Bruce, C. D. (2007). Effects of professional development on teacher efficacy: results of randomized field trip. Paper presented at the American Research Association Annual meeting of American Research Association, Chicago.

24. Shidler, L. (2009). Impact of time spent on coaching for teacher efficacy on student achievement. Early Childhood Education Journal, 36, 453-460.

25. Sternberg, R.J. \& Williams, W.M (2202). Educational Psychology. Boston, Allyn \& Bacon. 
26. Swackhamer, L. E., Koellner, K., Basile, C., \& Kimbrough, D. (2009). Increasing self-efficacy of inservice teachers through content knowledge: Teacher Education Quarterly, Spring, 63-78.

27. Tournaki, N., Lyublinskaya, T., \& Carolan, B. V. (2009). Pathways to teacher certification: does it really matter when it comes to efficacy and effectiveness. Action in Teacher Education, 30, 4, 96-109.

28. Tschannen-Moran, M., \& Hoy, A. W. (2001). Teacher efficacy: capturing an elusive construct. Teacher Education and Practice, 17, 783-805.

29. Tschannen-Moran, M., \& Hoy, A. W. (2007). The differential antecedents of self- efficacy beliefs of novice and experienced teachers. Teaching and Teacher Education, 236, 944-956.

30. Ware, H., \& Kitsantas, A. (2007). Teacher and collective efficacy beliefs as predictors of professional commitment. The Journal of Educational Research, 100, 5, 303-309.

31. Wolters, C. A., \& Daughtery. (2007). Goal structures and teachers' sense of efficacy: their relation and association of teaching experience and academic level. Journal of Educational Psychology, 99, 1, 181-193. 


\section{NOTES}

